\title{
PENGARUH BRAND EQUITY TERHADAP CONSUMER SATISFACTION DI RESTORAN SUSHI TEI JAKARTA SELATAN
}

\author{
Sri Wulandari \\ Program Studi Magister Manajemen Universitas Tarumanagara \\ sriwulandaripamungkas69@gmail.com
}

\begin{abstract}
This study aims to examine the effects of physical quality, staff behavior, brand identification and lifestyle on the satisfaction of Sushi tei restaurant consumers in Jakarta. This research was conducted by spreading questionnaires to 150 respondents who are all Sushi tei consumers in Jakarta. The result data of the next questionnaire is processed by using regression analysis technique which its processing will be done with the help of SPSS program. The result of analysis shows that physical quality variable, staff behavior, brand identification and lifestyle either partially or simultaneously have a positive and significant effect on the satisfaction of Sushi tei consumer in restaurant Jakarta. Furthermore, the result of analysis shows that physical quality, staff behavior, brand identification and lifestyle simultaneously affect the satisfaction of Sushi tei consumer in South Jakarta with contribution of $73,7 \%$.
\end{abstract}

Keyword : Brand equity, Consumer Satisfaction, Sushi Tei

\section{PENDAHULUAN}

Berdasar data yang disampaikan oleh Menteri dalam Negeri (Mendagri) RI Tjahjo Kumolo, jumlah penduduk Indonesia sekitar 182.588 .494 jiwa di tahun (2015). Dan peningkatan penduduk Indonesia 257.912.349 jiwa di tahun (2016). Penduduk saat ini masih di angka $1,49 \%$ atau lebih dari 262 juta jita di tahun (2017)

Seiring besarnya pertumbuhan penduduk dan tinggi nya konsumsi masyarakat Indonesia. Hasil survey MasterCard bertajuk Consumer Purchasing Priorities yang dilakukan(Nielsen, 2009) pada tahun (2015) menunjukkan bahwa sebanyak 80\% orang Indonesia lebih memilih untuk makan di gerai makan cepat saji, diikuti oleh pusat jajanan yang menempati urutan kedua dengan $61 \%$, dan restoran/kafe kelas menengah sebanyak 22\% (www.swa.co.id) Oleh sebab itu, peluang usaha di bidang restoran ini semakin tinggi.

Berikut adalah daftar top brand restoran sushi di Indonesia berdasarkan survey dilakukan oleh Frontier Consulting Group. Restoran Sushi tei menempati urutan pertama Top Brand Index restoran sushi di Indonesia sejak tahun (2014) hingga tahun (2016), meskipun terjadi penurunan presentase brand index sebesar 11,9\% dari tahun (2015) ke tahun (2016). Sushi tei di dirikan pada tahun (1994) di Singapura. Dan di Indonesia membuka gerai pertama pada tahun (2003) di Mall Plaza Indonesia. Mengacu pada banyak nya merek menurut American marketing association (2008), mendefinisikan merek sebagai nama, istilah, tanda, lambang atau desain kombinasi yang di maksud untuk mengidentifikasikan barang atau jasa dari salah satu penjual atau kelompok.

Sushi tei juga di tuntut untuk memiliki kepekaan terhadap setiap perubahan yang terjadi dan menempatkan orientasi kepada kepuasan pelanggan sebagai tujuan utama. Kotler dan Keller (2012) salah satu kunci kesuksesan suatu perusahaan adalah bagaimana usaha perusahaan tersebut dapat memenuhi kebutuhan dan keinginan konsumen. Schiffman dan Kanuk (2008), disamping kepuasan konsumen, kualitas servis menjadi fokusan utama dalam bidang jasa restoran. Model SERVQUAL, terdiri dari lima dimensi kualitas layanan: tangibles, keandalan, daya tanggap, jaminan, dan empati (Chao, 2008). Ada pun menurut Brady\& Cronin (2001) mengusulkan dua dimensi kualitas kualitas fisik dan prilaku staff. Kualitas fisik adalah gambaran yang di proyeksikan oleh desain, peralatan, fasilitas. Sedangkan prilaku staff 
adalah gambaran dari keramahan, bantuan, kerapihan, dan daya tanggap karyawan (Ekinci et al.,2008).

Berdasarkan latar belakang tersebut. Maka dari itu peneliti tertarik ingin menganalisia konsumen lebih lanjut faktor-faktor apa saja yang mempengaruhi kepuasan konsumen secara efektif. Peneliti tertarik untuk melakukan penelitian yang berjudul "Pengaruh Brand Equity Terhadap Consumer Satisfaction di restoran Sushi tei Jakarta Selatan"

\section{METODE PENELITIAN}

\section{Populasi dan Sampel}

Populasi dalam penelitian ini adalah seluruh konsumen yang pernah mengunjungi restoran Sushi tei di (Mall Ciputra World dan Mall Kota Kasablanka di Jakarta Selatan) Apabila jumlah populasi tidak diketahui, menurut (Hair dkk dalam Prawira 2010) merekomendasikan jumlah sampel minimal adalah 5 kali dari jumlah item pertanyaan yang terdapat di kuesioner, sehingga jumlah sampel yang diambil dalam penelitian ini adalah sebesar 150 responden, yang pernah mempunyai pengalaman makan di resoran Sushi tei atau sedang berada di area lokasi restoran Sushi tei cabang Mall Ciputra World dan Mall kota Kasablanka di Jakarta Selatan.

\section{HASIL PENELITIAN DAN PEMBAHASAN}

\section{Analisis Regresi}

Uji asumsi dalam analisis regresi linear berganda meliputi uji normalitas, uji multikolinearitas, uji heteroskedastisitas dan uji autokorelasi.

\section{Uji Asumsi Klasik}

\section{Uji Normalitas}

Uji Normalitas dilakukan untuk mengetahui distribusi residual dari model regresi, jika residual berdistribusi normal maka model dapat dianalisis dengan analisis regresi, namun jika residual tidak berdistribusi normal maka model tersebut tidak dapat dianalisis dengan analisis regresi. Berikut ini adalah hasil dari uji normalitas Kolmogorv Sminov dengan bantuan program SPSS:

\section{Hasil Uji Normalitas Kolmogorv Smirnov}

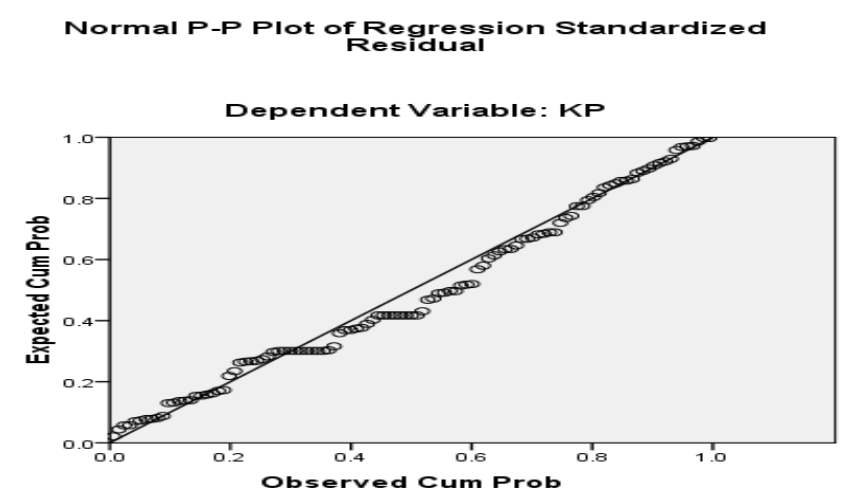

Pada grafik diatas, peneliti melakukan uji normalitas pada model penelitian ini yaitu pengaruh brand equity terhadap kepuasan konsumen restoran Sushi tei di Jakarta Selatan. Berdasarkan uji normalitas melalui normal probability plot (p-p plot) diketahui bahwa residual data menyebar di sekitar garis diagonal dan mengikuti arah garis diagonal, maka model ini memenuhi asumsi normalitas.

\section{Uji Multikolinearitas}

Hasil uji multikolinearitas pada tabel 4.4 menunjukkan bahwa nilai VIF seluruh variabel bebas < 10 dan nilai tolerance seluruh varabel bebas telah melebihi 0,1. Hal ini menunjukkan bahwa model regresi telah memenuhi asumsi multikolinearitas. 
Tabel 10 Hasil Uji Multikolinearitas

Coefficients $^{\mathrm{a}}$

\begin{tabular}{|c|c|c|c|}
\hline \multirow{2}{*}{\multicolumn{2}{|c|}{ Model }} & \multicolumn{2}{|c|}{ Collinearity Statistics } \\
\hline & & Tolerance & VIF \\
\hline \multirow[t]{4}{*}{1} & Kualitas_Fisik & .543 & 1.842 \\
\hline & Penilaian_Staf & .588 & 1.702 \\
\hline & $\begin{array}{l}\text { Identifikasi_Mere } \\
\mathrm{k}\end{array}$ & .450 & 2.222 \\
\hline & Gaya_Hidup & .483 & 2.070 \\
\hline
\end{tabular}

a. Dependent Variable: Kepuasan_Pelanggan

\section{Hasil Analisis Regresi}

Hasil analisis regresi linear berganda meliputi hasil uji pengaruh parsial (uji t), uji pengaruh simultan (uji F) dan koefisien determinasi (R square).

\section{Uji Parsial (Uji t)}

Dalam analisis regresi linear berganda, uji parsial (uji t) digunakan untuk menguji pengaruh parsial masing-masing variabel bebas terhadap variabel terikat. Hipotesis pengujian yang digunakan dalam pengujian ini adalah sebagai berikut :

Ho : variabel bebas secara parsial tidak berpengaruh terhadap kepuasan konsumen Sushi tei di Jakarta Selatan

Ha : variabel bebas secara parsial berpengaruh terhadap kepuasan konsumen Sushi tei di Jakarta Selatan

Dengan tingkat kepercayaan 95\%, maka Ho akan ditolak jika nilai signifikan $<0,05$ dan Ho akan diterima jika nilai signifikan $>0,05$.

\section{Tabel 13 Hasil Uji Parsial}

Coefficients $^{\mathbf{a}}$

\begin{tabular}{|r|r|r|r|r|r|}
\hline & \multicolumn{2}{|c|}{$\begin{array}{c}\text { Unstandardiz } \\
\text { ed } \\
\text { Coefficients }\end{array}$} & $\begin{array}{c}\text { Standardiz } \\
\text { ed } \\
\text { Coefficient } \\
\mathrm{s}\end{array}$ & \multicolumn{1}{c|}{$\mathrm{t}$} & \multicolumn{1}{c|}{ Sig. } \\
\cline { 2 - 6 } Model & \multicolumn{1}{c|}{$\begin{array}{c}\text { Std. } \\
\text { Error }\end{array}$} & \multicolumn{1}{c|}{ Beta } & & \\
\hline $1 \quad$ (Constant) & .309 & .518 & & .597 & .552 \\
Kualitas_Fisik & .250 & .043 & .336 & 5.812 & .000 \\
Perilaku_Staf & .128 & .042 & .170 & 3.062 & .003 \\
Identifikasi_ & .160 & .064 & .160 & 2.513 & .013 \\
Merek & & & & & \\
Gaya_Hidup & .197 & .033 & .365 & 5.950 & .000 \\
\hline
\end{tabular}

a. Dependent Variable: Kepuasan_Pelanggan

Berdasarkan hasil uji parsial, diperoleh beberapa hasil sebagai berikut :

a. Nilai signifikansi pengaruh variabel kualitas fisik terhhadap kepuasan konsumen Sushi tei di Jakarta Selatanadalah sebesar 0,000 dengan koefisien regresi bertanda positif. Oleh karena nilai signifikansi yang diperoleh $<0,05$ dan koefisien regresi bertanda positif maka Ho ditolak dan disimpulkan bahwa kualiats fisik berpengaruh positif dan signifikan terhadap kepuasan konsumen Sushi tei di Jakarta Selatan. 
Semakin baik kualitas sushi tei di restoran tersebut maka semakin tinggi kepuasan konsumen Sushi tei di Jakarta Selatan, begitu sebaliknya.

b. Nilai signifikansi pengaruh variabel Perilaku Staf terhadap kepuasan konsumen Sushi tei di Jakarta Selatan adalah sebesar 0,003 dengan koefisien regresi bertanda positif. Oleh karena nilai signifikansi yang diperoleh $<0,05$ dan koefisien regresi bertanda positif maka Ho ditolak dan disimpulkan bahwa perilaku staf berpengaruh positif dan signifikan terhadap kepuasan konsumen Sushi tei di Jakarta Selatan. Semakin baik perilaku staf sushi tei di restoran tersebut maka semakin tinggi kepuasan konsumen Sushi tei di Jakarta Selatan, begitu sebaliknya.

c. Nilai signifikansi pengaruh variabel identifikasi merek terhhadap kepuasan konsumen Sushi tei di Jakarta Selatan adalah sebesar 0,013 dengan koefisien regresi bertanda positif. Oleh karena nilai signifikansi yang diperoleh $<0,05$ dan koefisien regresi bertanda positif maka Ho ditolak dan disimpulkan bahwa identifikasi merek sushi tei berpengaruh positif dan signifikan terhadap kepuasan konsumen Sushi tei di Jakarta Selatan. Semakin mudah identifikasi merek sushi tei di restoran tersebut maka semakin tinggi kepuasan konsumen Sushi tei di Jakarta Selatan, begitu sebaliknya.

d. Nilai signifikansi pengaruh variabel Gaya hidup terhadap kepuasan konsumen Sushi tei di Jakarta Selatan adalah sebesar 0,000 dengan koefisien regresi bertanda positif. Oleh karena nilai signifikansi yang diperoleh $<0,05$ dan koefisien regresi bertanda positif maka Ho ditolak dan disimpulkan bahwa gaya hidup masyarakat berpengaruh positif dan signifikan terhadap kepuasan konsumen Sushi tei di Jakarta Selatan. Semakin tinggi gaya hidup masyarakat di sekitar restoran tersebut maka semakin tinggi kepuasan konsumen Sushi tei di Jakarta Selatan, begitu sebaliknya.

\section{Uji Simultan (Uji F)}

Dalam analisis regresi lnear berganda, uji pengaruh simultan digunakan untuk menguji pengaruh seluruh variabel bebas secara bersama-sama terhadap variabel terikat. Hipotesis pengujian yang digunakan dalam pengujian ini adalah sebagai berikut :

Ho : seluruh variabel bebas secara simultan tidak berpengaruh terhadap kepuasan konsumen Sushi tei di Jakarta Selatan

Ha : seluruh variabel bebas secara simultan berpengaruh terhadap kepuasan konsumen Sushi tei di Jakarta Selatan

Dengan tingkat kepercayaan 95\%, maka Ho akan ditolak jika nilai signifikan $<0,05$ dan Ho akan diterima jika nilai signifikan $>0,05$

Tabel 14 Hasil Uji Simultan

ANOVA ${ }^{b}$

\begin{tabular}{|ll|r|r|r|r|r|}
\hline \multicolumn{2}{|l|}{ Model } & \multicolumn{1}{|c|}{$\begin{array}{c}\text { Sum of } \\
\text { Squares }\end{array}$} & df & Mean Square & F & Sig. \\
\hline 1 & Regression & 213.682 & 4 & 53.421 & 101.417 & $.000^{\mathrm{a}}$ \\
& Residual & 76.378 & 145 & .527 & & \\
& Total & 290.060 & 149 & & & \\
\hline
\end{tabular}

a. Predictors: (Constant), Gaya_Hidup, Perilaku_Staf, Kualitas_Fisik, Identifikasi_Merek

b. Dependent Variable: Kepuasan_Pelanggan 
Berdasarkan hasil analisis regresi pada tabel 4.8 di atas, diperoleh nilai signifikan hasil uji $\mathrm{F}$ sebesar 0,000. Oleh karena nilai signifikan hasil uji simultan $<0,05$ maka Ho ditolak dan disimpulkan bahwa variabel kualitas fisik, perilaku staf, identifikas merek dan gaya hidup secara simultan berpengaruh terhadap kepuasan konsumen Sushi tei di Jakarta Selatan

\section{Koefisien Determinasi}

Dalam analisis regresi linear berganda, koefisien determinasi menunjukkan besar pengaruh simultan variabel bebas terhadap variabel terikat. Nilai koefisien determinasi dilihat dari nilai R Square.

Tabel 15 Koefisien Determinasi Model Summary ${ }^{\mathrm{b}}$

\begin{tabular}{|l|r|r|r|r|}
\hline Model & \multicolumn{1}{|c|}{$\mathrm{R}$} & R Square & $\begin{array}{c}\text { Adjusted R } \\
\text { Square }\end{array}$ & $\begin{array}{c}\text { Std. Error of } \\
\text { the Estimate }\end{array}$ \\
\hline 1 & $.858^{\mathrm{a}}$ & .737 & .729 & .72577 \\
\hline
\end{tabular}

a. Predictors: (Constant), Gaya_Hidup, Penilaian_Staf, Kualitas_Fisik, Identifikasi_Merek

b. Dependent Variable: Kepuasan_Pelanggan

Hasil analisis regresi pada tabel 4.8 menunjukkan bahwa nilai R Square model regresi adalah sebesar 0,588. Hal ini menunjukkan bahwa besar kontribusi yang diberikan kualitas fisik, perilaku staf, identifikas merek dan gaya hidup terhadap kepuasan konsumen sushi tei adalah sebesar $73,7 \%$, sedangkan sisanya sebanyak $26,3 \%$ variansi kepuasan konsumen sushi tei dapat dipengaruhi oleh faktor lain di luar kualitas fisik, perilaku staf, identifikas merek dan gaya hidup.

\section{PEMBAHASAN HASIL PENELITIAN}

\section{Pengaruh Kualitas Fisik terhadap kepuasan konsumen}

Nilai signifikansi pengaruh variabel kualitas fisik terhhadap kepuasan konsumen Sushi tei di Jakarta Selatanadalah sebesar 0,000 dengan koefisien regresi bertanda positif. Oleh karena nilai signifikansi yang diperoleh $<0,05$ dan koefisien regresi bertanda positif maka Ho ditolak dan disimpulkan bahwa kualiats fisik berpengaruh positif dan signifikan terhadap kepuasan konsumen Sushi tei di Jakarta Selatan. Semakin baik kualitas sushi tei di restoran tersebut maka semakin tinggi kepuasan konsumen Sushi tei di Jakarta Selatan, begitu sebaliknya.

\section{PENUTUP}

\section{Kesimpulan}

Kesimpulan yang diperoleh dari hasil penelitian ini adalah sebagai berikut :

Kualitas Fisik berpengaruh positif dan signifikan terhadap kepuasan pengguna konsumen Sushi tei di Jakarta Selatan. Semakin baik kualitas fisik restoran Sushie tei maka semakin tinggi kepuasan pengguna konsumen Sushi tei di Jakarta Selatan, begitu sebaliknya.

Perilaku Staf tidak berpengaruh signifikan terhadap kepuasan pengguna konsumen Sushi tei di Jakarta Selatan. Semakin baik perilaku staf maka semakin semakin tinggi kepuasan pengguna konsumen Sushi tei di Jakarta Selatan, begitu sebaliknya.

Identifikasi Merek berpengaruh positif dan signifikan terhadap kepuasan pengguna konsumen Sushi tei di Jakarta Selatan. Semakin baik identifikasi merek maka semakin tinggi kepuasan pengguna konsumen Sushi tei di Jakarta Selatan, begitu sebaliknya. 
Gaya Hidup berpengaruh positif dan signifikan terhadap kepuasan pengguna konsumen Sushi tei di Jakarta Selatan. Semakin tinggi gaya hidup konsumen maka semakin tinggi kepuasan pengguna konsumen Sushi tei di Jakarta Selatan, begitu sebaliknya.

Kualitas fisik, perilaku staf, identifikasi merek dan gaya hidup secara simultan berpengaruh terhadap kepuasan pengguna konsumen Sushi tei di Jakarta Selatan dengan kontribusi sebesar $73,7 \%$.

\section{Saran}

\section{Bagi restoran Sushi Tei Jakarta}

Restoran perlu memperbaiki ruangan sehingga visualisasinya semakin tinggi

Restoran perlu meningkatkan brand imagenya misal dengan melakukan promosi sehingga identifikasi merek semakin tinggi

\section{Bagi penelitian selanjutnya}

Penelitian selanjutnya diharapkan dapat menambah variabel penelitian di luar variabel yang telah diteliti dalam penelitian ini, karena hasil analisis menunjukkan masih sebanyak 41,2\% variansi kepuasan pengguna konsumen Sushi tei di Jakarta Selatan dipengaruhi oleh faktor lain di luar Kualitas fisik, perilaku staf, identifikasi merek dan gaya hidup konsumen.

\section{DAFTAR PUSTAKA}

Aulia Siswi Putriandari (2010), "Analisis Pengaruh Kualitas Jasa dan Kepuasan Pelanggan Terhadap Loyalitas Pelanggan Pengguna Telkom Speedy di Semarang".

Arti Pelayanan Bagi Restoran Sushi tei Agustus 4 (2015)

https://www.google.co.id/search?q=makanan+jepang+shusi+tei+di+jakarta+kompas.com\&hl $=$ en\&ei=TxakWu6GMszqvASgrpTwBg\&start=10\&sa=N\&biw=1366\&bih=667

Ghozali, Imam. (2009). Aplikasi Analisis Multivariate Dengan Program SPSS. Edisi Keempat. Semarang: Badan Penerbit Universitas Diponegoro

Hancer \& Erkmen. (2015), "Linking Brand Commitment and Brand Citizenship Behavior of Airline Employess; "'The Role Of Trus". 47-54.

I Komang Gede Mahendra. (2008).“ Jurnal Siasat Bisnis Pengaruh Kualitas Layanan Terhadap Kepuasan Konsumen Pada Hotel Griya Sunset Kuta”. 129-147.

Iglesias, Oriol, Singh, Jatinder J. \& Batista, Joan M (2001). "The Role Of Brand Experience and Affective Commitment in Determining Brand Loyalty Journal Of Brand Management." 18, 570-582.

J. Nam et al., (2011). “Brand Equity, Brand Loyalty, And Consumer Satisfaction”. 10091030. 


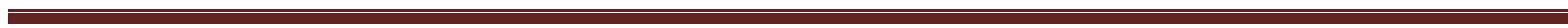
$\cdot$ 